\title{
MRTFB Gene
}

National Cancer Institute

\section{Source}

National Cancer Institute. MRTFB Gene. NCI Thesaurus. Code C142159.

This gene plays a role in the coactivation of transcription. 